\title{
Kentsel Aktörlerin Sürdürülebilirlik Algıları: Q-Metodoloji Yöntemiyle Bir Araştırma*
}

\author{
Sustainability Perceptions of Urban Actors: A Research with Q-Methodology Method
}

\author{
Dr. Öğr. Üyesi Levent MEMiş̧ ${ }^{1} 1$
}

\begin{abstract}
$\ddot{\mathbf{O} z}$
Sürdürülebilirlik yaklaşımı, karşılaşılan toplumsal, ekonomik ve çevresel sorunlara bir çözüm aracı olarak 1970'li yıllardan itibaren gündeme gelmeye başlamış ve zaman içinde farklı konularda karşılık bularak popülerliğini artırmıştır. Sürdürülebilirlik yaklaşımının, diğer konuların (tarım, ormancılık, balıkçlık, yoksulluk gibi) yanında gündeme alındığı önemli bir alanda kentsel yerleşimlerdir. Barındırdığı nüfus ve yerleşim özelliklerinden dolayı ayırıcı yönleri bulunan kentlerde karşılaşılan sorunlara bir çözüm aracı olarak sürdürülebilirlik yaklaşımı gündeme gelmektedir. Bu bağlamda araştırmanın temel amacı, kentsel mekanlarda sorumluluk üstlenen aktörlerin sürdürülebilirlik algılarını ölçmek ve özelde de atık yönetimine ne derece önem verdiklerini tespit etmektir. Araştırmada, belirlenen sürdürülebilir kentsel kalkınma kriterleri üzerinden uzlaşının ve farklılıkların, aktörler arasında nasıl bir dağılım gösterdiği inceleme konusu yapılmaktadır. Araştırmada, Q-Metodoloji yöntemi kullanılmaktadır. Belirlenen kapsam (Giresun ili) çerçevesinde araştırmaya altı STK ve yedi belediye dahil edilmiştir. Araştırmanın genel sonuçlarına göre belediyelerde, çevre ana başlığı altındaki konularda hem uzlaşmanın (enerji verimliliği, bisiklet, toplu taşıma, çevre eğitimi gibi) hem de farklılaşmanın (yeşil işletme, atık yönetimi, tarım alanları ve su kaynakları gibi) olduğu tespit edilmektedir. Diğer taraftan STK'larda da çevre başlı̆̆ altındaki konularda uzlaşı bulunurken, sosyo-kültürel ana başlı̆g altındaki konularda farklılaşmanın olduğu anlaşılmaktadır. Atık yönetimi bağlamında ele alındığında ise hem STK'ların hem de belediyelerin, kaynakta ayrıştırma ve geri dönüşüm dahil olmak üzere, atık yönetimi konusuna 1 ile 4 aralığında (büyük oranda) önem verdikleri anlaşılmaktadır.
\end{abstract}

Anahtar Kelimeler: Sürdürülebilirlik, sürdürülebilir kentsel kalkınma, kentsel aktörler, Q-Metodoloji

Makale Türü: Araştırma

\begin{abstract}
The sustainability approach has started to come to the agenda as a means of solution to the social and economic problems encountered in the 1970s and its popularity has increased by finding answers on different issues over time. Urban settlements are important areas where sustainability approach is put on the agenda. The main purpose of the research is to measure the sustainability perceptions of the actors who take responsibility in urban spaces that contain the density of the population and to determine the importance they attach to waste management in particular. In this research, the distribution of the differences and consensus among the actors based on the determined sustainable urban development criteria is examined. In the research, Q-Methodology method is used with its unique structure. The data obtained by this method were analysed using PQMethod 2.0 software. The scope of the study consists of the province of Giresun. In this context, six NGOs (non-governmental organizations) and seven municipalities were included in the study. According to the general results of the research, it is determined that there are both consensus (such as energy efficiency, cycling, public transportation,
\end{abstract}

\footnotetext{
* Bu çalışma, "Sürdürülebilir Kentsel Kalkınma ve Katı Atık Yönetimde Ağ Yönetişimi: Giresun İli Örneği” (Sakarya Üniversitesi, SBE, 2016) başlığı altında, Prof. Dr. H. İbrahim AYDINLI danışmanlığında hazırlanan doktora tezinden türetilmiştir.

${ }^{1}$ Giresun Üniversitesi, İktisadi ve İdari Bilimler Fakültesi, levent_memis@hotmail.com.
}

Atıf için (to cite): Memiş, L. (2019). Kentsel aktörlerin sürdürülebilirlik algıları: Q-metodoloji yöntemiyle bir araştırma. Afyon Kocatepe Üniversitesi Sosyal Bilimler Dergisi, 22(1), 244-260. 
environmental education) and differentiation (such as green enterprise, waste management, agricultural areas and water resources). On the other hand, while NGOs have reached consensus on environmental issues, it is understood that there is differentiation on issues under socio-cultural main head. The consensus of CSOs on the environment reflects the results of their environment-oriented study areas. In the context of waste management, it is understood that both NGOs and municipalities give great importance to waste management in the range of 1 to 4, including separation and recycling at source.

Keywords: Sustainability, sustainable urban development, urban actors, Q-Methodology

Paper Type: Research

\section{Giriş}

İnsanın yaşamasını sağlayan kaynakların aşırı kullanımı bir takım olumsuz sonuçlarla karşılaşılmasına yol açmış ve ortaya çıkan bu durum yeni arayışlara sebep olmuştur. Bilim ve teknolojideki gelişmelerin etkisi altında kaynakların tüketildiği bu süreçte, kaynakların devamlılığına aracı olmayı öngören sürdürülebilirlik kavramı gündeme gelmiştir. Hatta zaman içinde bir yaklaşımı temsil etmeye başlamıştır. İlk aşamada çevresel sorunlar üzerinden gündeme gelen kavram, sanayi toplumunda karşılaşılan olumsuzluklarla, farklı alanlarda (çevre, nüfus, ekonomi, kentleşme, vb.) ele alınmaya başlanmıştır. Sürdürülebilirlik yaklaşımı 1960'lı yıllarda ortaya çıkan çevresel hareketlerin etkisiyle 1970'li yılların başından itibaren uluslararası düzeyde karşılık bulmaya başlamıştır. İlgi yoğunluğunun artmasıyla (bkz. Wheeler, 1996, s. 28) yaklaşım yaygınlık kazanmış ve farklı alanlarda gündeme gelerek popüler bir kavram haline gelmiştir (Engelmen, 2013, s. 3).

Genel olarak mevcut ekonomik yapıya da uyumluluğu yansıtan sürdürülebilirlik kavramının, öncesinde "sürdürülebilir toplum" (sustainable community), sonrasında ise "sürdürülebilir kalkınma" (sustainable development) şeklinde kullanımının yaygınlaştığ anlaşılmaktadır. Kavramın temel odağı; ekonomi, toplum ve çevre arasında bir dengenin kurulmasına dayanmaktadır. Diğer taraftan sürdürülebilir kalkınma yaklaşımı, büyümenin nimetlerinden yararlanmayan ve aşırı yoksulluk içinde olan toplum kesimlerini (Kılınç, 2011, s. 16) ve gelecek kuşakları merkezine yerleştirmektedir. Fakat kavram beraberinde bir takım eleştirileri de getirmektedir. Bu bağlamda; büyüme ne kadar imkan dahilinde olacaktır?, büyümenin biçimi ne olacaktır?, gelişmekte olan ülkelerin beklentilerini karşıllayabilecek midir? gibi sorulardan hareketle sahip olduğu kimi belirsizliklerin altı çizilmektedir (Fiorino, 2010, s. 583). Bunların yanında, biyolojik çeşitliliği koruma, yoksulluğu azaltıcı yöntemlerin geliştirilmesi, atıkların azaltılması, fosil yakıtlara bağlılı̆̆ın azaltılması gibi zorlukların bulunduğuna da dikkat çekilmektedir (Maczulak, 2010, s. 175-177).

Sürdürülebilir kalkınma yaklaşımının önemli unsurlarından biri de mekânsal boyutudur. Mekân gündeme geldiğinde de, öncelikli yaşam mekânımızı oluşturan kentler öne çıkmaktadır. $\mathrm{Bu}$ noktada sürdürülebilir kalkınma yaklaşımına kent mekânı üzerinden odaklanıldığında, "sürdürülebilir kentsel kalkınma" kavramı gündeme gelmektedir. Dünya nüfusunun yarıdan fazlasını bünyesinde barındıran kentler; sosyal, ekonomik ve çevresel açıdan birçok sorunla karşı karşıya kalmaktadır. Adı geçen sorunları giderme ve daha iyi bir yaşam mekânı inşa etme çabasıyla kentsel düzlemde sürdürülebilirlik yaklaşımı karşılığını bulmaktadır. Fakat bu süreçte de mikro, makro ve meso düzeyde çeşitli faktörlerin etkili olduğu bilinmektedir (Zavadskas, Kaklauskas, Vainiünas ve Saparauskas, 2004, s. 219-221). Burada üzerinde önemli durulmas1 gereken başka bir husus ise; çevresel, sosyal ve ekonomik açıdan etkileme ve etkilenme durumu bulunan farklı taraflardan (kamu, özel ve sivil toplum) aktörlerin, sürdürülebilirlik konusundaki farkındalıklarıdır. Bu olmadan sürdürülebilir bir mekân inşa etmek veya mekânı sürdürülebilir hale getirmek mümkün gözükmemektedir.

Sürdürülebilirlik yaklaşımının kentsel alanda karşılığını bulmasındaki önemli bir husus ise, kent yönetimine dâhil olan aktörlerin farkındalığı ve bilgisidir. Bu bağlamda araştırmanın temel amacı, kentsel mekânlarda sorumluluk üstlenen aktörlerin sürdürülebilirlik algılarını 
ölçmek ve özelde de atık yönetimine ne derece önem verdiklerini tespit etmektir. Ayrıca araştırmada, belirlenen sürdürülebilir kentsel kalkınma kriterleri üzerinden uzlaşının ve farklılıkların, aktörler arasında nasıl bir dağılım gösterdiği inceleme konusu yapılmaktadır. Araştırmada, kendine özgün yapısıyla Q-Metedoloji yöntemi kullanılmaktadır. Bu yöntemle elde edilen veriler PQMethod 2.0 programından yararlanılarak analiz edilmiştir.

\section{Kavramsal Çerçeve: Sürdürülebilirlik}

Genel düzeyde ele alındığında sürdürülebilirlik, uzun dönemli bir bakış açısını yansıtan (Newman ve Kenworthy, 2000, s. 109), soyut ve geniş konsept bir kavram olarak (Portney, 2003 , s. 3) gündeme gelmektedir. Kavramın ilk kullanımı (sustain) 1290 yılına kadar geriye götürülmekle (Scoones, 2007, s. 590; Leach, Scoones ve Stirling, 2010, s. 37) birlikte, modern anlamda kullanımı 1970'li yılların başlarından itibaren gerçekleştirilen toplantılarda ${ }^{2}$ ve yaşanan gelişmelerin etkisi altında ortaya çıkmaya başlamıştır. $\mathrm{Bu}$ süreç içinde kavramın yaygınlaşmasında çeşitli faktörlerin etkili olduğu anlaşılmaktadır. Bu bağlamda nüfus artışıyla gündeme gelen potansiyel sorunlar (1798 tarihli Thomas Malthus'un çalışması), çevre sorunlarını ele alan yayınlar [The Outermost House (1928); Sessiz Bahar (1962); Uygunsuz Gerçek (2006) vb.], STK faaliyetleri, toplantılar, özel gün (Eart Day gibi) kutlamaları, çevrecilik akımlarının yaygınlaşması, ekolojik yaklaşımlar, insan eylemlerinin sınırlandırılmasına yönelik çalışmalar ve 1973 yılında gerçekleşen petrol ambargosu gibi olaylar etkili olmuştur. Diğer taraftan nüfusta yaşanan artışla birlikte; sosyal eşitsizliklerin artması, kentleşme sürecinin devam etmesi, kaynaklara (enerji, su, materyaller gibi) olan talebin artmasi, biyolojik çeşitliliğin ve yaşam alanlarının yok olması, iklim değişikliğinin yaşanması, endüstri ve tarım alanlarında fazla enerji ve materyal tüketen üretim yöntemlerinin devam etmesi gibi değişen şartların da etkili olduğu bilinmektedir (Lehmann, 2012, s. 105).

Sürdürülebilir yaklaşımın ortaya çıkması ve benimsenerek yaygınlaşmaya başlaması sürecine genel olarak bakıldığında; endüstrileşmenin, kentleşmenin ve teknolojinin yarattığ çevresel etkilerin, 1960'larda gerçekleşen çevresel hareketlerin ortaya çıkmasına kadar önemli derecede fark edilmediği, bu nedenle "ekonomik ve çevresel sistemler" arasındaki ilişkiye dair herhangi bir vurgunun yapılmadığı görülmektedir. Ancak 1970'li yıllara gelindiğinde, politik ve kurumsal değişimler gerçekleşmeye başlamıştır. Sürdürülebilirlik yaklaşımı, Stockholm Zirvesi ve BM Çevre Programı'nın 1972 yılında oluşturulmasıyla uluslararası düzeyde karşılığını bulmaya başlamıştır (Fiorino, 2010, s. 581). Bu bağlamda daha fazla dengeli bir sürdürülebilirlik için 3E: "Çevre, Ekonomi ve Adalet" (tree "Es": Environment, Economy ve Eguity) kavramlarının altı çizilmektedir (Saha ve Paterson, 2008, s. 22; Edwards, 2005, s. 2123). Burada sürdürülebilirliğin, ne sadece ekonomiye odaklanarak, ne de sadece çevresel unsurlara odaklanarak ortaya çıkmayacağ 1 vurgulanmakta, sürdürülebilirliğin ifade edilen $3 \mathrm{E}$ kavramları arasında bağlantı ve bağlılık oluşturularak ortaya çıkacağı öne sürülmektedir (Saha ve Paterson, 2008, s. 26). Bu sayede uzun süreli, gelecek kuşakları dikkate alan bir toplumsal yapı ortaya çıkabilecektir.

Tarihsel süreç içinde ortaya çıkan gelişmeler ile birlikte sürdürülebilirlik, ekonomik ve politik yapı içinde gücünü giderek artırmış, "doğa ve toplum" için iyiyi temsil eden yeni bir ahlaki değerler silsilesi ortaya çıkarmıştır (Aykan, 2014, s. 244). Gündeme gelen bu değerler; bireysel yaşamdan örgütsel yaşama, üretimden ticarete, kamusal perspektiften özel alana, kırdan kentte gibi birçok alanda iş yapma biçimini, bireylerin yaşamını etkilemektedir. Diğer taraftan sürdürülebilirliğin, tek bir değişkene veya tek bir düzleme indirgenerek gerçekleştirilmeyeceği önemle vurgulanmakta, birçok değişken ve düzlem arasındaki etkileşim/bağlantılar aracılığıyla mümkün olacağı öngörülmektedir. Sürdürülebilirlik için kentsel düzeyde; ulaşım, sağlık, eğitim, barınma gibi hususlar, bölgesel düzeyde; erişilebilir kaynaklar ve toplulukların çevresi, ulusal

\footnotetext{
2 Örneğin bir kaynakta (Wheeler, 1996: 1-2) "sürdürülebilir toplum" (sustainable society) ifadesinin ilk kez 1974 yllında gerçekleştirilen bir konferansta (Conference of World Council of Churches) kullanıldığ ifade edilmektedir.
} 
ve uluslararası düzeyde ise; enerji, gıda, sağlı, vergi gibi konular hükümet politikalarında önemli rol oynamaktadır (Edwards, 2005, s. 29).

\section{Sürdürülebilir Kentsel Kalkınma}

Sürdürülebilirliğin ilk gündeme geldiği dönemlerde kapsamlı, topyekûn farklı bir paradigmayı yansıtan bir kavram olarak sürdürülebilir toplum (sustainable community) kavramının kullanıldığı anlaşılmaktadır (Portney, 2003, s. 3). Süreç içinde uluslararası oluşumların da etkisiyle sürdürülebilir kalkınma kavramı ön plana çıkmaya başlamıştır. Sürdürülebilir kalkınma kavramı; küresel, ulusal ve ulus altı düzlemde, konvansiyonel kalkınma (conventional development) (Eley, 2008, s. 43) veya büyüme odaklı/GSMH'ye odaklı ekonomik (Kılınç, 2011: 12) yaklaşımdan farklı bir zihniyet değişimini simgeleyen popüler bir kavram olarak ortaya çıkmaktadır (Harmon, 2008, s. 94). Sürdürülebilir kalkınma, klasik kalkınma yaklaşımında ortaya çıkan sorunların (yoksulluk, işsizlik, gelir dağılımı eşitsizliği, doğal çevrenin tahribatı gibi), özellikle az gelişmiş ülkelerde giderilmesi vaadiyle, insan merkezli bir anlayışı benimsemektedir (Zafir, 2014, s. 244-245). Sürekli ve dengeli (sürdürülebilirlik) kalkınma şeklinde de ifade edilen sürdürülebilir kalkınma kavramı; ekonomi, toplum ve çevre arasında kurulmak istenen dengenin bir ifadesi olarak kurgulanmaktadır (Keleş ve Hamamcı, 2005, s. 169). Sürdürülebilir kalkınma kavramının uluslararası alanda ifadesi ilk kez BM Çevre ve Kalkınma Komisyonu'nca hazırlanan ve 1987 yılında yayınlanan “Ortak Geleceğimiz z" adlı yazanakta gerçekleşmiştir (Keleş ve Hamamc1, 2005, s. 169; Demir, 2013, s. 69; Kılınç, 2011, s. 17). Bu rapor ile doğal çevre, sürdürülebilir kalkınma kavramı altında ilk defa politik öncelikler arasına girmiştir (Breheny, 1996, s. 10). Yaşanan bu gelişmelerle birlikte, sürdürülebilir kalkınma kavramı; çevre sorunları, az gelişmişlik, nüfus artışı gibi politikalarda merkezi konuma gelmiştir (Zafir, 2014, s. 250).

Mekânsal boyut, ekonomik, çevresel ve sosyo-kültürel bileşenlerinin yanında sürdürülebilirlik için vurgulanan diğer bir husustur (Dinler, 2014, s. 181). Bu bağlamda gündeme gelen mekânsal alan ise kentlerdir. Kentler, teknolojik gelişmenin etkisi altında, özellikle 20. yy.'ın ikinci yarısından itibaren sanayinin gelişmesiyle, daha iyi yaşama arzusu veya zorunlu sebeplerle, nüfus yığınlarının yaşama alanı olarak tercih ettiği yerler olarak öne çıkmaktadır. Bu özellikleri nedeniyle kentler, kırsal yaşamdan farklı olarak, yeni bir toplumsal işbölümü ile ekonomik, politik ve dinsel düzeni sağlayarak uygarlığın merkezine konumlandırılmaktadır (Bumin, 2010, s. 5-6).

Kentler, çeşitli alt sistemlerden (yol, materyaller, barınma, taşıma, enerji, hava kalitesi, ekonomi, kültür, eğitim, sağlık, eğlence kurumları gibi) oluşan yaşam alanı olarak işlev görmekte (Cohen, 2011, s. 106-107), bünyesinde barındırdığı sakinlerine daha iyi yaşam beklentisini giderici; refah, küresel ekonomik firsatlara erişim ve diğer birtakım olanaklar vaat etmektedir. Kentler, daha iyi yaşam alanı oluşturma sürecinde çeşitli problemlerle karşı karşıya gelmektedir. $\mathrm{Bu}$ bağlamda kentsel alanda ortaya çıkan sosyal sorunlar; büyük sosyal eşitsizlikler, yabancılaşma ve kentsel yoksulluklar (gelir yoksunluğu, suç, sosyal dışlanma, anti sosyal davranışlar gibi) şeklinde görülmektedir. Ekonomik sorunlar; küreselleşmenin hız kazanmasıyla kentlerin büyük sanayi kuruluşlarını ve önceki ekonomik özelliklerini kaybetmesi, girişim ve gelir adaletsizliğin artması, belediyelerin finans ihtiyacının artması, temel alt yapı ve kamusal hizmetlere erişimin azalması olarak karşılık bulmaktadır. Çevresel sorunlar ise; yetersiz sağlı önlemleri ve kirliliğin (atık, hava, gürültü, toprak ve su) halk sağlığını etkilemesi, küresel ısınma ve sera gazı oluşumunda kentlerin birinci derecede etkili olması, iklim değişikliği ile birlikte ortaya çıkan olumsuz durumlar (sera gazı, tarım alanlarının yok olması, kirlilik gibi), bilinçsiz arazi kullanımı, mikro klima etkisi, 1s1 adalarının ortaya çıkması, yeşil alanların yetersizliği, daha fazla enerji ihtiyacının duyulması, yağış miktarı ve

\footnotetext{
${ }^{3}$ Sürdürülebilirliğe odaklanan bir çok çalışmada (Cohen , 2011, s. 1; Fiorino, 2010, s. 579; Mori ve Christodoulou, 2012, s. 95; Portney, 2008, s. 580; Portney ve Berry, 2010, s. 2; Rana, 2009, s. 507;, Rydin, 2010, s. 2; Tanguay, Rajaonson, Lefebvre ve Lanoie, 2010, s. 407 vb.) kavramın çıkış noktası olarak verilen bu eser gösterilmektedir.
} 
sıcaklığın değişmesi, kentsel düzlemden küresel 1sınmayı etkileyen faktörler olarak ortaya çıkmaktadır (Çetinkaya, 2013, s. 13; Keivani, 2010, s. 7-13; Rydin, 2010, s. 11-12). İşte tüm bu gerekçelerle, sürdürülebilir kalkınmanın gerçekleştirilmesi için en önemli alanlar olarak kentler önemini korumakta olup (Jenks, Burton ve Williams, 1996: 3), sürdürülebilirlik bağlamında kentlerin planlanması ve organizasyonun derinden düşünülmesi gereken bir husus olduğu ifade edilmektedir (Hiremath, Balachandra, Kumar, Bansode ve Mural1, 2013, s. 555).

Sürdürülebilirlik paradigmasının kentlere uyarlanmasıyla geliştirilen sürdürülebilir kentsel kalkınma (SKK) yaklaşımı, kentsel alanda ortaya çıkan sorunları giderici/azaltıcı öneriler sunmaktadır. İlk kez 1996 HABITAT II Zirvesi'nin sonuç bildirgesinde yan yana getirildiği ifade edilen (Tosun, 2010, s. 380) sürdürülebilirlik ve kent kavramlarının, ilgili literatürde bazı ortak kesişim noktaları üzerinden farklı şekillerde tanımlandığı görülmektedir. 2000 yılında URBAN 21 başlığında Berlin'de yapılan konferansta, sürdürülebilir kentsel kalkınma, kentsel mekânda; ekolojik, kültürel, politik, kurumsal, sosyal ve ekonomik bileşenleri içeren politikalarla, kentsel yaşam kalitesinin iyileştirilmesi süreci olarak tanımlanmaktadır (Karakurt, 2008, s. 81). Bu bağlamda farklı başlıklarda (ekonomik, sosyo-kültürel, çevresel, yönetişim ve kurumsal boyutlarıyla) göstergeler öne çıkmaktadır. Ortak göstergelerin belirlenipbelirlenmeyeceğine yönelik bazı tartışmalar (Furuseth ve Lord, 1999, s. 7; Rana, 2009, s. 510517; Scerri ve James, 2010) olmakla birlikte, sürdürülebilirlik odaklı amaç ve programların uygulanması için, sürdürülebilirlik göstergeleri önemli bir araç olarak düşünülmektedir (Harmon, 2008, s. 94). Ayrıca geniş kapsamlı toplumsal bir dönüşümü simgeleyen bu yeni kalkınma yaklaşımının gerçekleşmesinde birçok aktör ile iş birliği ve iletişim halinde olmanın gerekliliği belirtilmektedir (Agranoff ve McGuire, 2003, s. 143). Farklı yerel ve bölgesel paydaşlar ile iş birliğine gidilmesi, yapılan faaliyetlerin etkinliğini artıracağı kabul edilmektedir. Ayrıca özel sektör ve diğer paydaşların katılımıyla oluşan ortaklıkların daha fazla know-how'a izin verdiği de ifade edilmektedir. Bu bağlamda, çeşitli aktörler ile birçok ortaklıklar kurulmakla birlikte, özel sektörün girişimci know-how'u ve yerel know-how'un, kamusal siyasi know-how ile birleşmesiyle özel bir değer ortaya çıkabilmektedir. Ek olarak planlama ve uygulama sürecine insanların katılımıyla, güçlü bir sahiplik ve sorumluluk değeri oluşturulmasına yardımcı olacağı da bilinmektedir (Zavadskas ve diğerleri, 2004, s. 224; Promoting Sustainable Urban Development in EUROPE, 2009, s. 38-39).

Sürdürülebilirliğe yönelik göstergelerin; sürdürülebilirlik odaklı politikaların beklenen ve beklenmeyen etkilerinin değerlendirilmesi ve süreçlerin takip edilmesine yardımcı olması, son gelişmeler hakkında eğitici bir role sahip olması, geçmişte yapılanları doğrulamak/değerlendirmek için bir araç olması, ayrıca devletin açıklık ve hesap verebilirliğinin yükselmesine katkı sağlaması, karar alma sürecine doğru bilginin aktarılması gibi konularda hayati öneme sahip olduğunun altı çizilmektedir (Harmon, 2008, s. 96). Diğer taraftan yararlanılan sürdürülebilir kentsel kalkınma göstergeleri; giderilmesi gereken problemlerin anlaşılması, karşılaştırmaların yapılmasında (Mori ve Christodoulou, 2012, s. 96-97), politika uygulamalarının güçlü ve zayıf yönlerinin objektif olarak değerlendirilmesinde, ilgili görevlilere bir araç sunmaktadır (Furuseth ve Lord, 1999, s. 19).

1970’li yılların başında uluslararası ölçekte gündeme gelen sürdürülebilirlik yaklaşımı, 1990'lı yılların başından itibaren kent düzleminde ele alınmaya başlanmış ve çeşitli çabalar gerçekleştirilmiştir. Bu noktada Gündem 21 Eylem Planı (1992, Yeryüzü Zirvesi, Rio) ile sürdürülebilirlik yaklaşımı daha fazla yerel düzeyde somut hale getirilerek uygulanması kolaylaştırılmaya çalışılmıştır. Sonrasında ise; Avrupa Kentsel Şartı (1992), Avrupa Sürdürülebilir Kentler ve Kasabalar Konferansı (1994), HABITAT I-II-III toplantıları (1976, 1996 ve 2016), Rio+20 (2012) vb. başlıklar altında uluslararası düzeyde çabalar gösterilmeye devam edilmiştir. Diğer taraftan AB düzeyinde de; Sürdürülebilirliğe Doğru Avrupa Kentler ve Kasabalar Şartı (Aalborg Şartı) (1994), Lille Deklarasyonu (2000), Urbact (2003), Rotterdam Şartı (2004), Sürdürülebilir Toplumlar Üzerine Bristol Mutabakatı (2005), Sürdürülebilir Avrupa Kentleri için Leipzig Şartı (2007), Marsilya Bildirgesi (2008), AB Belediye Başkanları 
Şözleşmesi (2008), Toledo Bildirgesi (2010), Akıllı Kentler ve Topluluklar Alanında Avrupa İnovasyon Ortaklığı (2011), Avrupa Sürdürülebilir Kentler Platformu (2013), vb. çabalar kentsel sürdürülebilirliğe katkı sağlamak amacıyla gerçekleştirilmiştir (Özgül, 2015, s. 117; Tağmat, 2009; Kuban, 2014, s. 31).

Görüldüğü gibi sürdürülebilirlik yaklaşımı, çok boyutlu ve çok düzlemli bileşenleri barındırması nedeniyle uluslararası oluşumları zorunlu kılmaktadır. Başta BM ve AB olmak üzere, adı geçen oluşumlar, aldıkları kararlar ve gerçekleştirdikleri faaliyetler ile sürdürülebilir bir toplumun veya kentin oluşması için çaba sarf etmektedirler. Tamda bu noktada Cullinan (2014, s. 40), tek başına ulusal mevzuatın ve uluslararası anlaşmaların gerçekleştirilmesinin sürdürülebilir bir toplum için yeterli olmadığını vurgulamaktadır. Ayrıca yeryüzündeki topluluklar arasında karşıllklı olarak geliştirilen yeni bir anlayış temelinde düzenlemeler yapıldığında sürdürülebilir bir toplumun mümkün olacağı öne sürülmektedir.

\section{Yöntem}

$\mathrm{Bu}$ araştırmanın temel yöntemi, ilk kez İngiliz Fizikçi Psikolog William Stephenson tarafından 1935 yılında geliştirilen (Raje, 2007, s. 467) Q-Metodolojidir. Bu (daha çok) nitel araştırma yöntemiyle amaçlanan, ilk sıralarda yer alan aktörler ile alt sıralarda yer alan kentsel aktörlerin, kentsel sürdürülebilirliğe yönelik algılarını ölçmeye çalışılmaktır (Akbulut ve Beren, 2012, s. 276). Aynı zamanda bu yöntem, toplumun farklı alanlarından, farklı geçmişe sahip vatandaşların, sürdürülebilir kalkınmaya yönelik algıları/bakış açıları elde edilerek, dahil edici ve sosyal öğrenme yaklaşımlarından biri olarak işlev görebilme potansiyeli taşımaktadır (Doody, Kearney, Barry, Moles ve O'Regan, 2009, s. 1130). Bu yöntem sayesinde sürdürülebilirliğe yönelik kent yöneticilerin bakış açıları sistematik bir şekilde elde edilmekte ve yerel sürdürülebilirlik politikalarının uygulaması için daha iyi bir teorik açıklama getirmenin ilk aşaması olduğu kabul edilmektedir (Zeemering, 2009, s. 255). Bu yöntemin, bireylerin bir tutum geliştirdiği her bir olay ${ }^{4}$, olgu ve fikir için bir ölçüm arac1 olarak kullanılabileceği ifade edilmektedir (Demir ve Kul, 2011, s. 37).

$\mathrm{Bu}$ yöntem nitel (sübjektif görüş, alg1 ve davranışlara odaklanması) ve nicel (faktör analizinin uygulanması) özellikleri barındırmasına rağmen (Demir ve Kul, 2011, s. 29), bir hipotez sınama yöntemi değildir ve 25 ile 75 kişi aralığındaki katılımcıya uygulanabilmektedir (Skelcher, Sullivan ve Jeffares, 2013, s. 99; 101). Kara (2006, s. 22) da, bu yöntemin yapıs1 gereği cevaplayanların sayısının ya soru/cümle sayısı kadar ya da en fazla soru/cümle sayısının iki katı kadar olabileceğini vurgulamaktadır. Burada örneklem belirlenirken kentin toplumsal ve ekonomik kalkınması için çaba sarf eden, bu haliyle kentin büyüme stratejileri, çevresel düzenlemeleri ve toplumsal faaliyetleri hakkında bilgi sahibi olan aktörler dikkate alınmaktadır (Zeemering, 2009, s. 12-13). Ayrıca belirtmek gerekir ki, Q-Metodolojinin sübjektif algilar1 ölçmeye yönelik bir yöntem olması sebebiyle, evrenin tamamını temsil etme kaygısı taşımadığ (Akbulut ve Beren, 2012, s. 276) ve farklı örneklem sayılarında gerçekleştiği görülmektedir (Gültekin, Burak ve Yaşar, 2018, s. 3218).

Bu çalışmada Q-Metodoloji kapsamında, aktörlerin sürdürülebilirliğe yönelik bireysel algılarını ve önem derecelerini tespit etmek amacıyla ilgili literatür ${ }^{5}$ ve kentlerin yerel özgün özellikleri dikkate alınarak [yapısal tasarım yöntemi (Demir ve Kul, 2011, s. 42)], sürdürülebilirlik yaklaşımını yansıtan 36 ifadeden/cümleden oluşan Q Dizgisi geliştirilmiştir. Katılımcılardan, geliştirilen Q-Dizgisi içinde yer alan ifadelerin önem derecesine göre (en az önemliden en fazla önemliye), -4 ile 4 arasında belirlenen sınırlılıklar çerçevesinde sıralanması istenmiştir. Sıralama esnasında "zoraki dă̆glım" tekniği tercih edilmiştir. Bu teknikle,

\footnotetext{
${ }^{4}$ Ulaşım ve sosyal kapsayıcılık (Raje, 2007), sürdürülebilir kalkınma göstergelerine yönelik uzman görüşü ve halkın bakış açısını tanımlamak ve değerlendirmek (Doody ve diğerleri, 2009: 1130), feminist kadın hareketlerini medyaya yansıması (Kara, 2006), sosyal projelerden yararlananların ve yararlanmayanların terörle mücadele algısı (Akbulut ve Beren, 2012), biyomass'dan elde edilen enerji alternatifleri üzerine paydaş diyalogunun aracı olarak (Cuppen, Breukers, Hisschemöller ve Bergsma, 2010) ve çevresel sorunlara yönelik bireylerin nasıl düşündüğü üzerinedir (Barry ve Proops, 1999)

${ }^{5}$ Özellikle Zeemering, 2009'dan daha fazla yararlanılmıştır.
} 
araştırmacı tarafindan verilen şekle göre, Q-Dizini cümlelerinin dağılımının yapılması istenmektedir (Demir ve Kul, 2011, s. 48). Bu çalışmada Şekil 1'de gösterilen biçimiyle zoraki dağglım 36 ifade üzerinden gerçekleştirilmiştir. Dağılım belirlenmesinde yöntemin özellikleri dikkate alınmış (Demir ve Kul, 2011, s. 48), uç ifadelere az sayıda yer verecek biçimde hareket edilmiştir. Ayrıca bu yöntem aracılığıyla verilen cevapların nedenleri sorgulanmış ve katılımcıların diğer önemli gördüğü hususlar da not edilmiştir. Bu yöntem sayesinde, kentte bulunan ve kentin kalkınmasına katkı sağlayan aktörlerin; kalkınma konusunda hangi alanlara öncelik verdiği, verilen önceliklerin ne derece sürdürülebilirlik yaklaşımına katkı sağladığı ve böylece sürdürülebilirlik algılarının ne olduğu, taraflar dikkate alındığında hangi konularda konsensüs sağlandığı ve hangi konularda farklılıkların ortaya çıktığı, katı atıkların yönetimine ne derece önem atfedildiği tespit edilmiş olmaktadır. Ayrıca aktörler arasında sürdürülebilirlik konusunda bir farklılı̆̆ın olup-olmadığı da ortaya çıkarılmaktadır.

\begin{tabular}{|c|c|c|c|c|c|c|c|c|}
\hline \multicolumn{8}{|c|}{ Şekil 1. Zoraki dağılım şeması } & \multirow{2}{*}{$\begin{array}{c}\begin{array}{c}\text { En Fazla } \\
\text { Önemli }\end{array} \\
4 \\
\end{array}$} \\
\hline-4 & -3 & -2 & -1 & 0 & 1 & 2 & 3 & \\
\hline \multirow{4}{*}{2 Cümle } & & & & & & & & 2 Cümle \\
\hline & 3 Cümle & & & & & & 3 Cümle & \\
\hline & & 4 Cümle & & & & 4 Cümle & & \\
\hline & & & 6 Cümle & 6 Cümle & 6 Cümle & & & \\
\hline
\end{tabular}

Bu kapsamda Giresun ili örnekleminde, araştırmanın içeriği bağlamında dahil edilen altı $\mathrm{STK}^{6}$ ve yedi belediye ${ }^{7}$ yöneticisine, 36 ifade üzerinden Q-Metot yöntemi uygulanmıştır. Ayırıcı özellikleriyle bu yöntemin uygulanması fazla zaman almaktadır. Bu durum dikkate alınarak uygulama, yine belediye başkanlarının yönlendirmesiyle, belediyenin yaptığı/yapacağı işlere hâkim diğer bir yönetici (genellikle belediye başkan yardımcısı) tarafından gerçekleştirilmiştir. Ayrıca uygulama esnasında yapılan tercihlerin nedenleri hakkında sorular yöneltilmiş, detaylı bilgi elde edilmeye çalışılmıştır.

Elde edilen verilerin analizinde Peter Schmolck tarafindan geliştirilen PQ-Method yazılımından ${ }^{8}$ yararlanılmıştır. Önce STK ve belediye yöneticilerinden elde edilen veriler birlikte girilerek analiz edilmek istenmiştir. Fakat analiz neticesinde anlamlı sonuçlar elde edilemediği için STK ve belediye yöneticilerinin verileri ayrı ayrı girilerek analiz edilmiş, elde edilen sonuçlar karşılaştırmalı olarak yorumlanmaya çalışılmıştır. Verilerin yorumlanmasında; Frantzi, Carter ve Lovett, 2009; Barry ve Proops, 1999; Doody ve diğerleri, 2009 ve Zeemering, 2009 eserleri referans alınmıştır. Elde edilen verilere öncelikle faktör analizi uygulanmıştır. Analiz sonucunda elde edilen bulguların anlamlılı̆̆1, $\mathrm{SE}=\left(1 / \sqrt{\mathrm{n}}_{\mathrm{n}} .2,58\right.$ formül ile hesaplanmıştır. Yapılan bu hesaplama ile elde edilen sonuç ve üzerindeki değerler istatistiki olarak anlamlılığı yansıtmaktadır (Demir ve Kul, 2011, s. 85).

\section{Bulgular}

\subsection{Faktör Analizi Sonuçları}

Yapılan hesaplamaya göre 0,433 ve üzeri değerler istatistiki olarak anlamlı kabul edilmiştir. STK'ları yansıtan faktör analizi Tablo 1'de gösterilmektedir. Yapılan analiz sonucu beş faktör ortaya çıkmış olup, dört STK'nın görüşlerinin toplandığı A faktörü ön plana

\footnotetext{
${ }^{6}$ Çalışmanın kapsamı itibariyle konusu çevre olan STK'lar (Giresun Çevre ve Kültür Derneği, Giresun Çevre Derneği, Karadeniz Doğa Koruma Federasyonu, Tirebolu Çevre, Kültür ve Turizm Derneği, Görele Çevre ve Kültür Derneği ve Yağlidere Doğa Koruma ve Çevre Derneği) dahil edilmektedir.

${ }^{7}$ Giresun, Bulancak, Piraziz, Tirebolu, Keşap, Görele ve Espiye belediyeleri.

${ }^{8}$ Bkz.: http://schmolck.userweb.mwn.de/qmethod/downpqwin.htm (15.12.2015)
} 
çıkmaktadır. Diğerlerine bakıldığında, daha az bir yoğunlaşma ile; B ve C faktörünü iki STK, D ve E faktörlerinde ise bir STK'nın görüşlerinin etkili olduğu anlaşılmaktadır.

Tablo 1. Sivil toplum kurumlarının faktör analizi

\begin{tabular}{|c|c|c|c|c|c|}
\hline QSORT & $\mathbf{A}$ & B & $\mathbf{C}$ & D & $\mathbf{E}$ \\
\hline STK1 & 0.1939 & $-0.5453 X$ & $\underline{0.7616 X}$ & 0.1733 & 0.2288 \\
\hline STK2 & $0.8006 \mathrm{X}$ & -0.2479 & -0.2374 & 0.3500 & -0.1045 \\
\hline STK3 & $0.8543 \mathrm{X}$ & 0.1871 & -0.0459 & 0.2621 & -0.1881 \\
\hline STK4 & $\underline{0.6040 X}$ & 0.3214 & $\underline{0.5282 X}$ & -0.3891 & -0.2896 \\
\hline STK5 & $\underline{0.7389 X}$ & 0.3248 & -0.1426 & -0.1768 & $\underline{0.5446 \mathrm{X}}$ \\
\hline STK6 & -0.3980 & $0.7280 \mathrm{X}$ & 0.3318 & $0.4324 X$ & 0.0690 \\
\hline \% Expl.Var. & 41 & 19 & 17 & 10 & 8 \\
\hline
\end{tabular}

Tablo 2'de de belediyelere yönelik faktör analizi sonuçlarına yer verilmektedir. Analiz sonucunda üç faktör ortaya çıkmıştır. STK'lara kıyasla daha fazla bir yoğunlaşmanın olduğu, ilk etapta anlaşılmaktadır. Elde edilen analiz sonuçlarının içeriğine bakıldığında, altı belediye yöneticisinin görüşlerini yansıtan A faktörü ön plana çıkmaktadır. İkinci (B) grupta dört belediye yöneticisinin ifadeleri toplanmakta, üçüncü grupta ise yalnızca bir belediye yöneticisinin görüşlerinin etkili olduğu anlaşılmaktadır.

Tablo 2. Belediyelerin faktör analizi

\begin{tabular}{cccc}
\hline QSORT & A & B & C \\
\hline GBEL1 & $\underline{0.7262 X}$ & -0.1272 & -0.3870 \\
\hline GBEL2 & $\underline{0.5289 \mathrm{X}}$ & $\underline{0.6096 \mathrm{X}}$ & 0.2159 \\
\hline GBEL3 & $\underline{0.6943 \mathrm{X}}$ & $\underline{-0.4780 \mathrm{X}}$ & 0.1587 \\
\hline GBEL4 & 0.3277 & 0.0199 & $\underline{0.8371 \mathrm{X}}$ \\
\hline GBEL5 & $\underline{0.4484 \mathrm{X}}$ & $\underline{-0.6981 \mathrm{X}}$ & -0.1160 \\
\hline GBEL6 & $\underline{0.8154 \mathrm{X}}$ & 0.1456 & -0.0019 \\
\hline GBEL7 & $\underline{0.4847 \mathrm{X}}$ & $\underline{0.5975 \mathrm{X}}$ & -0.3386 \\
\hline \% Expl.Var. & $\mathbf{3 6}$ & $\mathbf{2 1}$ & $\mathbf{1 5}$ \\
\hline
\end{tabular}

Aşağıdaki yer verilen Tablo 3’te, STK ve belediyelerden elde edilen veriler sonucu analiz edilen faktörleri oluşturan ifadeler karşılaştırmalı olarak verilmektedir. Bu tabloda ayrı ayrı, STK ve belediyelerin faktör yüklerini oluşturan ifadeler yer almakta, belediye ile STK'ların uzlaşı içinde olduğu ve ayrıştığı ifadeler görülebilmektedir. Belediyelerden elde edilen faktör sonuçları incelendiğinde; 5, 7, 13, 14, 23, 25, 27, 28 ve 30 numaralı ifadelerde katılımcılar açısından belli bir uzlaşının varlığı anlaşılmaktadır. İfadeler incelendiğinde; dördünün çevre, üçünün sosyo-kültürel, birer tanesinin ise ekonomi ile yönetişim başlığı altında yer aldığı anlaşılmaktadır. İfadeler özelinde bakıldığında ise belediyeler, sürdürülebilirlik kapsamında komşu kentler ile diyaloğu kısmen önemli değil olarak görmektedirler (5). Bisiklet kullanımının yaygınlaştırılması için altyapı imkanlarının yaratılması ve teşvik edilmesi (7) ifadesine de tüm belediyeler aynı şekilde karşıllk vererek kısmen önemli olduğunu belirtmiştir. İşletmelerin ve hanelerin enerji verimliliğinin teşvik edilmesi (13) ifadesine iki faktörde çok 
önemli değil, bir faktörde de en az önemli konu olarak karș1lık verilmiștir. Yine ele alınan ilin nüfusu ve yerleşimi dikkate alınarak toplu taşıma araçlarının gereksinimi (14) büyük oranda çok önemli değil şeklinde ifade edilmiştir. Ekonomik kalkınmasına katkı sağlayacak mevcut işletmeleri ve çalı̧̧anları kaybetmemek için çaba sarf etmeyi (23), bazı katılımcılar tarafından bu durumun büyük oranda işletmenin kendi performansı ile ilişkili bir husus olduğunun altı çizilerek kısmen önemli değil şeklinde belirtilmiştir. Yine okullardaki çevresel eğitimlerin verilmesi ifadesine (25) ise kısmen önemli değil cevabı verilmiştir. Katılımcıların genellikle zaten okul müfredatlarında çevre eğitimlerinin yeterince olduğu düşünülerek bu karşıllk verildiği anlaşılmaktadır. Diğer taraftan yerel değerlerin ön plana çıktığı kültürel/sanatsal etkinlikler (27) tüm faktör düzeylerinde kısmen önemli görülmüştür. En güçlü uzlaşının olduğu konu ise çocuklar için oyun alanlarının oluşturulmasında (28) görülmektedir. İki faktör düzeyinde en önemli konu görülürken, bir faktör düzeyinde de çok önemli olduğu belirtilmiştir. Üzerinde olumlu anlamda uzlaşı sağlanan bir başka konu ise dezavantajlı birey ve toplulukların sosyal hayata katılımı (30) konusudur. Burada da iki faktör düzeyinde çok önemli, bir faktör düzeyinde de önemli görülmüştür.

Diğer taraftan yine belediyelerden elde edilen faktör sonuçları incelendiğinde, 12, 4, 17, 21, 24, 31 ve 33 numaralı ifadelerde büyük oranda ayrı düşünüldüğ̈̈ görülmektedir. Ortaya çıkan bu farklılıkların sebebi sorgulandığında, en önemli unsurun ilçe belediyelerinin nüfus ve yerleşim özellikleri ile il merkezi belediyesinin nüfus ve yerleşim özelliklerinin farklılaşmasından kaynaklandığı kanaatine varılmaktadır. Bu bağlamda yetersiz mahalleler için ulaşım hizmetleri (12) bir faktör içinde önemli değil şeklinde görülürken, diğer bir faktör içinde çok önemli görülebilmektedir. Yeşil işletmelerin teşvik edilmesi (4) iki faktörde nötr bir karşılık bulurken, bir faktörde en az önemli şeklinde karşılık bulmaktadır. İnternet aracılığıyla kamusal erişimin artırılması (17) ifadesine bir faktörde çok önemli görülürken, diğer faktörde çok önemli değil şeklinde cevap verilmekte ve bir diğer faktörde ise kısmen önemli olarak belirtilmektedir. Dezavantajlı topluluklar ve bireyler için daha çok yeni girişimlerin ortaya çıkarılması amacıyla finansman erişiminin sağlanması (21) ifadesine bir faktörde en fazla önemli olduğu belirtilmekte, diğer iki faktörde de kısmen önemli değil ve çok önemli değil şeklinde karşılık bulduğu anlaşılmaktadır. Ortaya çıkan atıkların çevre kirliliğine yol açamayacak şekilde yönetilmesine çaba sarf etmek (24) ifadesine ise iki faktörde çok önemli ve en fazla önemli şeklinde karşılık verilirken, diğer faktörde çok önemli değil cevabı ortaya çıkmaktadır. Tarım alanlarının ve su kaynaklarının korunmasına önem göstermek (31) ifadesine de iki faktörde kısmen önemli ve nötr cevap verilirken, bir faktörde ise en az önemli karşılığ 1 verilmiştir. Sağlığın korunması ve sağlıklı yaşama katkı sağlayacak faaliyetlerin yapılması ifadesine ise bir faktörde kısmen önemli değil, bir faktörde kısmen önemli ve diğer faktörde ise en az önemli olduğu açıklanmıştır.

Yukarıda ifade edilenler çerçevesinde belediye verilerinden hareketle elde edilen faktör sonuçları genel olarak değerlendirildiğinde, çevre ana başlığı altında yer alan konularda uzlaşmanın ve farklılaşmanın yoğunlaştığı anlaşılmaktadır. Bu bağlamda yeşil işletme, atıkların yönetimi, tarım alanları ve su kaynakları, sağlı̆̆ın koruması ve sağlıklı yaşam konularında büyük oranda aynı düşünülmediği; bisiklet, enerji verimliliği, toplu taşıma ve çevresel eğitim konularında ise büyük oranda aynı düşünüldüğü tespit edilmektedir

Tablo 3.Faktörlere göre sürdürülebilir kentsel kalkınma ifadelerinin ortalamaları

\begin{tabular}{|c|c|c|c|c|c|c|c|c|}
\hline \multirow[b]{2}{*}{ Sürdürülebilir Kentsel Kalkınma İfadeleri } & \multicolumn{8}{|c|}{ Faktörler } \\
\hline & A1 & A2 & B1 & B2 & C1 & $\mathbf{C 2}$ & D1 & E1 \\
\hline $\begin{array}{l}\text { 1. Yeni girişimlerin ortaya çıkması için finansman firsatları } \\
\text { yaratmak }\end{array}$ & -3 & -2 & 1 & -2 & -1 & 0 & 1 & -3 \\
\hline 2. Yeni ürünlerin ve hizmetlerin ortaya çıkmasını teşvik etmek & -1 & -4 & 2 & -3 & -4 & 2 & 2 & -2 \\
\hline $\begin{array}{l}\text { 3. Bilgi teknolojileri ve telekomünikasyon altyapısının gelişmesini } \\
\text { teşvik etmek }\end{array}$ & -2 & -2 & 0 & 0 & -4 & 0 & 0 & -3 \\
\hline $\begin{array}{l}\text { 4. Kullanılan teknoloji, ürünün içeriği, atığın ortaya çıkmasını } \\
\text { azaltan yapısıyla yeşil işletmelerin teşvik edilmesi }\end{array}$ & 2 & -4 & -1 & 0 & 1 & 0 & -1 & 0 \\
\hline 5. Sürdürülebilirlik yaklaşımı kapsamında komşu kentler ile & -1 & 0 & 3 & -1 & 3 & -1 & 3 & -1 \\
\hline
\end{tabular}


diyalogu ve iletişimi geliştirmek

\begin{tabular}{lcccccccc}
\hline 6. Açık/yeşil kamusal alanların geliştirilmesini sağlamak & 4 & 2 & 0 & 3 & 1 & -1 & 0 & 2 \\
\hline 7. Yaya ve bisiklet yolları için alt yapı geliștirmek ve kullanımı & 2 & 1 & -2 & 1 & 0 & 1 & -2 & 3
\end{tabular} teşvik etmek



azaltılması için çalışmalar yapmak

9. Kentsel dönüşümün, mevcut yaşayanlara ve kültürlerine zarar $\quad \begin{array}{llllllllll} & 1 & -1 & -1 & 2 & 4 & 1 & -1 & -2\end{array}$

vermeyecek şekilde yapılmasına çaba sarf etmek

10. İşsizlerin istihdam olanağını artırmak için mesleki eğitime $\quad \begin{array}{llllllllll}-4 & 2 & 3 & 0 & -3 & -2 & 3 & -3\end{array}$

destek olmak

\begin{tabular}{lccccccccc}
\hline 11. Yerelde üretilen ürünlerin yaygınlaşmasına katkı sağlamak & 0 & 0 & 2 & -2 & 0 & 1 & 2 & -1 \\
\hline 12. Yetersiz mahalleler için ulaşım hizmetlerinin genişlemesini & -1 & 0 & -2 & 3 & 0 & -2 & -2 & -1
\end{tabular} sağlamak

13. İşletmelerin ve hanelerin enerji verimliliğini teşvik etmek

14. Toplu taşıma araçlarını teşvik etmek

15. Eğitim yaşındaki çocukların ve gençlerin eğitim almalarını sağlamak için destek olmak

16. Biçimsel eğitimin dışında kent içinde eğitime yönelik $\quad \begin{array}{lllllllll} & -1 & -2 & 1 & -1 & -3 & 0 & 1 & 0\end{array}$ etkinlikler yapmak

17. İnternet aracılığıyla daha fazla bilgi sağlayarak toplum kalkınması için kamusal erişimi artırmak

18. Kadın-erkek eşitliğinin gerçekleşmesi için çaba sarf etmek

19. Kentte bulunan kurum, kuruluş ve işletmelerin sürdürülebilir

yaklaşımı benimsemelerine destek olmak

20. Yeniden yatırım için iş temsilcileri ve toplum liderlerini bir $\quad \begin{array}{llllllllll}-3 & 2 & 4 & 0 & 1 & -1 & 4 & -2\end{array}$ araya getirmek

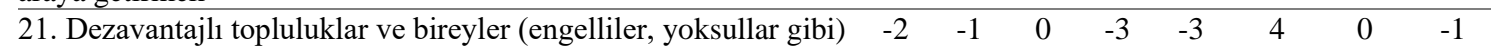

finansman erişimini sağlamak

\begin{tabular}{lccccccccc}
\hline 22. Kent içindeki mevcut iş alanlarını güzelleştirmek, geliştirmek & 0 & 2 & 0 & -1 & 2 & -1 & 0 & -1 \\
\hline 23. Mevcut işletmeleri ve çalışanları kaybetmemek için çaba sarf & -2 & -1 & 3 & -1 & -2 & 0 & 3 & -1
\end{tabular} etmek

24. Çeşitli şekillerde ortaya çıkan atıkların, çevresel kirliliğe yol $\quad \begin{array}{llllllllll} & 1 & 3 & 1 & 4 & -1 & -3 & 1 & 1\end{array}$ açmayacak şekilde çaba sarf etmek

25. Okullarda çevresel eğitim için destek olmak

\begin{tabular}{lcccccccc}
\hline 26. Mahalleleri geliştirecek programların gerçekleştirilmesi & 1 & 1 & -4 & 2 & 0 & 2 & -4 & 3 \\
\hline 27. Yerel değerlerin ön plana çıktığı kültürel/sanatsal etkinlikler & 0 & 1 & 1 & 1 & 4 & 1 & 1 & 0
\end{tabular} gerçekleştirmek

\begin{tabular}{lcccccccc}
\hline 28. Çocuklar için oyun alanlarının oluşmasına destek olmak & 2 & 3 & -4 & 4 & 0 & 4 & -4 & 2 \\
\hline 29. Planlama, kalkınma ve yatırım kararlarına, katılımcı olarak, & 1 & 4 & 4 & 1 & -1 & 3 & 4 & 3
\end{tabular} vatandaşları ve STK'ları dahil etmek

30. Dezavantajlı topluluklar ve bireylerin sağlıklı yaşamasını ve $\quad \begin{array}{lllllllll}1 & 3 & -3 & 2 & 2 & 3 & -3 & 0\end{array}$ sosyal hayata katılımını artırmak için çalışmalar yapmak

31. Tarım alanlarının ve su kaynaklarının korunmasına önem göstermek

32. Uygun fiyatlı konutlar için destek olmak

33. Sağlığın korunması ve sağlıklı yaşama katkı sağlayacak faaliyetler gerçekleştirmek

34. Kent ile ilgili karmaşık sorunların giderilmesi için farklı tarafların bir araya gelmesine çaba sarf etmek

35. Spor organizasyonlarına ve sportif faaliyetler için gerekli alanların oluşturulmasına destek olmak

36. Katı atıkların kaynakta ayrıştırılmasını ve geri dönüşümünü sağlamak

\section{\% Expl. Variance}

$*$ Variance $=4.500$ St. Dev. $=2.121$

*A1, B1, C1, D1 ve E1 sütundaki bilgiler STK'lara; A2, B2 ve C2 sütundaki bilgiler ise belediyelere aittir.

STK'lardan elde edilen faktör sonuçları incelendiğinde, belediyelere kıyasla STK'ların dağınık bir görüntü sergilediği anlaşılmaktadır. Özellikle uzlaşıya varılmayan ifadelerde bu dağınık durum ortaya çıkmaktadır. Bu bağlamda; $14,24,34,5,8,12,19$ ve 22 numaralı ifadelerde büyük oranda bir uzlaşı ortaya çıkmaktadır. Diğer taraftan; 2, 6, 7, 9, 10, 15, 16, 17 , $8,20,23,25,26,27,28,29,30,31,32,33,35$ ve 36 numaralı ifadelerde ise büyük oranda 
uzlaşının olmadığı anlașılmaktadır. Uzlaşılan konularda, daha çok çevre başlı̆̆ ifadeler ön plana çıkarken, uzlaşılmayan konularda ise sosyo-kültürel ana başlığı altındaki konuların ön plana çıktığı anlaşılmaktadır. Çevre üzerinde uzlaşının olması, STK'ların çevre odaklı çalışma alanlarının bir sonucunu yansıtmaktadır.

STK ve Belediyelerden elde edilen faktör verilerinin tamamına bakıldığında ise; 1,14 , $8,32,27,29$ ve 34 numaralı ifadelerde uzlaşıldığı; bunun yanında 10, 24, 31, 33, 18, 28, 20 ve 17 numaralı ifadelerde ise aynı düşünülmediği, uzlaşılmadığ 1 görülmektedir. Örneğin, kentte meydana gelen hırsızlık olaylarının giderilmesi ve azaltılması (8) konusunda tüm faktör düzeyinde katılımcıların büyük dilimi çok önemli değil ve en az önemli şeklinde ifade etmişlerdir. Diğer taraftan planlama, kalkınma ve yatırım kararlarında farklı tarafların dahil edilmesi (29) ifadesine ise, tüm faktör düzeylerinde katılımcıların büyük oranı çok önemli ve en fazla önemli şeklinde cevap vermişlerdir. Benzer şekilde atık gibi karmaşık sorunların giderilmesinde farklı tarafların bir araya getirilmesine çaba sarf etmek (34) ifadesine de tüm faktör düzeylerinde, büyük oranda önemli, çok önemli ve en fazla önemli karşıllğ 1 verilmiştir. Farklı faktör düzeylerinde uzlaşılma sağlanamayan ifadeler incelendiğinde ise, örneğin atıkların çevreye zarar vermeyecek şekilde yönetilmesi (24) ifadesine bir faktör düzeyinde çok önemli değil cevabı verilirken, diğer bir faktörde ise en fazla önemli cevabı verilmektedir. Bu durum bir katılımcı grubu faktörleri arasında görülmektedir. Yine tarım alanlarının ve su kaynaklarının korunmasına önem verilmesi (31) hususunda ise, bir katılımcı grubun oluşturduğu faktörde en fazla önemli denilirken, diğer katılımcı grubun oluşturduğu faktörlerden birinde ise en az önemli ifadesinde bulunulmaktadır.

Tablo 4. Belediye yöneticilerinin kentte en az önem verdiği konular ile en fazla önem verdiği konular

\begin{tabular}{|c|c|c|}
\hline & -4 & +4 \\
\hline GBEL1 & $\begin{array}{l}\text { Kentsel dönüşümün, mevcut yaşayanlara ve } \\
\text { kültürlerine zarar vermeyecek şekilde yapılmasına } \\
\text { çaba sarf etmek (9) } \\
\text { İnternet aracılığıyla daha fazla bilgi sağlayarak } \\
\text { toplum kalkınması için kamusal erişimi artırmak (17) }\end{array}$ & $\begin{array}{l}\text { İşsizlerin istihdam olanağını artırmak için } \\
\text { mesleki eğitime destek olmak (10) } \\
\text { Kent ile ilgili karmaşık sorunların giderilmesi } \\
\text { için farklı tarafların bir araya gelmesine çaba } \\
\text { sarf etmek (34) }\end{array}$ \\
\hline GBEL2 & $\begin{array}{l}\text { Kentte bulunan kurum, kuruluş ve işletmelerin } \\
\text { sürdürülebilir yaklaşımı benimsemelerine destek } \\
\text { olmak (19) } \\
\text { Kentte meydana gelen hırsızlık gibi olayların } \\
\text { giderilmesi ve azaltılması için çalışmalar yapmak (8) }\end{array}$ & $\begin{array}{l}\text { Yetersiz mahalleler için ulaşım hizmetlerinin } \\
\text { genişlemesini sağlamak (12) } \\
\text { Kentsel dönüşümün, mevcut yaşayanlara ve } \\
\text { kültürlerine zarar vermeyecek şekilde } \\
\text { yapılmasına çaba sarf etmek (9) }\end{array}$ \\
\hline GBEL3 & $\begin{array}{l}\text { Toplu taşıma araçlarını teşvik etmek (14) } \\
\text { Yetersiz mahalleler için ulaşım hizmetlerinin } \\
\text { genişlemesini sağlamak (12) }\end{array}$ & $\begin{array}{l}\text { Katı atıkların kaynakta ayrıştırılmasını ve geri } \\
\text { dönüşümünü sağlamak (36) } \\
\text { Yeniden yatırım için iş temsilcileri ve toplum } \\
\text { liderlerini bir araya getirmek (20) }\end{array}$ \\
\hline GBEL4 & $\begin{array}{l}\text { Kentte meydana gelen hırsızlık gibi olayların } \\
\text { giderilmesi ve azaltılması için çalışmalar yapmak (8) } \\
\text { Tarım alanlarının ve su kaynaklarının korunmasına } \\
\text { önem göstermek (31) }\end{array}$ & $\begin{array}{l}\text { Çocuklar için oyun alanlarının oluşmasına } \\
\text { destek olmak (28) } \\
\text { Dezavantajlı topluluklar ve bireyler (engelliler, } \\
\text { yoksullar gibi) finansman erişimini sağlamak } \\
(21)\end{array}$ \\
\hline GBEL5 & $\begin{array}{l}\text { Kentsel dönüşümün, mevcut yaşayanlara ve } \\
\text { kültürlerine zarar vermeyecek şekilde yapılmasına } \\
\text { çaba sarf etmek (9) } \\
\text { Uygun fiyatlı konutlar için destek olmak (32) }\end{array}$ & $\begin{array}{l}\text { Tarım alanlarının ve su kaynaklarının } \\
\text { korunmasına önem göstermek ( } 31) \\
\text { Spor organizasyonlarına ve sportif faaliyetler } \\
\text { için gerekli alanların oluşturulmasına destek } \\
\text { olmak (35) }\end{array}$ \\
\hline GBEL6 & $\begin{array}{l}\text { Kullanılan teknoloji, ürünün içeriği, atığın ortaya } \\
\text { çıkmasını azaltan yapısıyla yeşil işletmelerin teşvik } \\
\text { edilmesi (4) } \\
\text { Yeni ürünlerin ve hizmetlerin ortaya çıkmasını teşvik } \\
\text { etmek (2) }\end{array}$ & $\begin{array}{l}\text { Kent ile ilgili karmaşık sorunların giderilmesi } \\
\text { için farklı tarafların bir araya gelmesine çaba } \\
\text { sarf etmek (34) } \\
\text { Planlama, kalkınma ve yatırım kararlarına, } \\
\text { katılımcı olarak, vatandaşları ve STK'ları dahil } \\
\text { etmek (29) }\end{array}$ \\
\hline GBEL7 & $\begin{array}{l}\text { Dezavantajlı topluluklar ve bireyler (engelliler, } \\
\text { yoksullar gibi) finansman erişimini sağlamak (21) } \\
\text { Yerelde üretilen ürünlerin yaygınlaşmasına katkı } \\
\text { sağlamak (11) }\end{array}$ & $\begin{array}{l}\text { Açık/yeşil kamusal alanların geliştirilmesini } \\
\text { sağlamak (6) } \\
\text { Çocuklar için oyun alanlarının oluşmasına } \\
\text { destek olmak (28) }\end{array}$ \\
\hline
\end{tabular}


Tablo 5. Sivil Toplum Kurumlarının kentte en az önem verdiği konular ile en fazla önem verdiği konular

\begin{tabular}{|c|c|c|}
\hline & -4 & +4 \\
\hline STK1 & $\begin{array}{l}\text { Yeni ürünlerin ve hizmetlerin ortaya çıkmasını teşvik } \\
\text { etmek (2) } \\
\text { Bilgi teknolojileri ve telekomünikasyon altyapısının } \\
\text { gelişmesini teşvik etmek (3) }\end{array}$ & $\begin{array}{l}\text { Yerel değerlerin ön plana çıtıtı̆̆ } \\
\text { kültürel/sanatsal etkinlikler gerçekleştirmek } \\
(27) \\
\text { Kentsel dönüşümün, mevcut yaşayanlara ve } \\
\text { kültürlerine zarar vermeyecek şekilde } \\
\text { yapılmasına çaba sarf etmek (9) }\end{array}$ \\
\hline STK2 & $\begin{array}{l}\text { Yeniden yatırım için iş temsilcileri ve toplum liderlerini } \\
\text { bir araya getirmek }(20) \\
\text { Kadın-erkek eşitliğinin gerçekleşmesi için çaba sarf } \\
\text { etmek (18) }\end{array}$ & $\begin{array}{l}\text { Okullarda çevresel eğitim için destek olmak } \\
(25) \\
\text { Açık/yeşil kamusal alanların geliştirilmesini } \\
\text { sağlamak (6) }\end{array}$ \\
\hline STK3 & $\begin{array}{l}\text { İssizlerin istihdam olanağını artırmak için mesleki } \\
\text { eğitime destek olmak (10) } \\
\text { Uygun fiyatlı konutlar için destek olmak (32) }\end{array}$ & $\begin{array}{l}\text { Kent ile ilgili karmaşık sorunların giderilmesi } \\
\text { için farklı tarafların bir araya gelmesine çaba } \\
\text { sarf etmek (34) } \\
\text { Açı/yeşil kamusal alanların geliştirilmesini } \\
\text { sağlamak (6) }\end{array}$ \\
\hline STK4 & $\begin{array}{l}\text { Bilgi teknolojileri ve telekomünikasyon altyapısının } \\
\text { gelişmesini teşvik etmek (3) } \\
\text { Kentte meydana gelen hırsızlık gibi olayların } \\
\text { giderilmesi ve azaltılması için çalışmalar yapmak (8) }\end{array}$ & $\begin{array}{l}\text { Kent ile ilgili karmaşık sorunların giderilmesi } \\
\text { için farklı tarafların bir araya gelmesine çaba } \\
\text { sarf etmek (34) } \\
\text { Sağlığın korunması ve sağlıklı yaşama katkı } \\
\text { sağlayacak faaliyetler gerçekleştirmek (33) }\end{array}$ \\
\hline STK5 & $\begin{array}{l}\text { Uygun fiyatlı konutlar için destek olmak (32) } \\
\text { Kentte meydana gelen hırsızlık gibi olayların } \\
\text { giderilmesi ve azaltılması için çalışmalar yapmak (8) }\end{array}$ & $\begin{array}{l}\text { Kadın-erkek eşitliğinin gerçekleşmesi için } \\
\text { çaba sarf etmek (18) } \\
\text { Tarım alanlarının ve su kaynaklarının } \\
\text { korunmasına önem göstermek (31) }\end{array}$ \\
\hline STK6 & $\begin{array}{l}\text { Çocuklar için oyun alanlarının oluşmasına destek olmak } \\
\text { (28) } \\
\text { Mahalleleri geliştirecek programların gerçekleştirilmesi } \\
\text { (26) }\end{array}$ & $\begin{array}{l}\text { Planlama, kalkınma ve yatırım kararlarına, } \\
\text { katılımcı olarak, vatandaşları ve STK'ları dahil } \\
\text { etmek (29) } \\
\text { Yeniden yatırım için iş temsilcileri ve toplum } \\
\text { liderlerini bir araya getirmek (20) }\end{array}$ \\
\hline
\end{tabular}

Yukarıda yer verilen Tablo 4 ve 5 de ise, çalışmamızın odağı da dikkate alınarak katılımcıların bulundukları kentlerde en fazla önem verdikleri/verilmesi gerektiğini düşündükleri konular ile en az önem verdikleri/ verilmesi gerektiğini düşündükleri konular bir araya derlenmiştir. Tablolar incelendiğinde en fazla önem verilen ölçütte; 9, 6, 29, 31, 34 ve 20 numaralı ifadeler belediye ve STK'lar tarafindan aynı derecede karşılık bulmaktadır. Hatta karmaşık sorunlarda farklı tarafların bir araya gelmesi (34) iki belediye ve iki STK tarafindan verilen cevaplarda daha yüksek düzeyde bir konuma sahip olmaktadır. Ortak diğer ifadelerin içeriğine bakıldığında, yönetişim ve çevre başlığındaki konuların ön plana çıktığ anlaşılmaktadır. Bunların dışında ayrı ayrı bakıldığında belediyelerin en fazla önem verdiğ $i$ diğer konular; 10, 12, 36, 28, 21 ve 35 şeklinde öne çıkmaktadır. Burada çocuklar için oyun alanları (28) en fazla önem verilen konular arasından iki katılımcının katılımıyla diğerlerinden daha fazla önem kazanmaktadır. Diğer en fazla önem verilen ifadelerin içeriğine bakıldığında; öncelikle ekonomik unsurların görüldüğü, sonrasında ise sosyo-kültürel ve çevre başlıklarının ön plana çıktığı anlaşılmaktadır. STK'lar açısından en fazla önem verilen konulara bakıldığında da; 27, 25, 33 ve 18 ifadelerinin yer aldığı tespit edilmektedir. Bu ifadelerin içeriği incelendiğinde de, çevre ile sosyo-kültürel başlıkların öne çıktığı görülmektedir. Diğer taraftan en az önemli görülen ölçütte ise; 2, 8 ve 32 numaralı ifadeler belediye ve STK'lar tarafından aynı derecede karşılık bulmaktadır. Yine burada da, hırsızlık (8) ve uygun fiyatlı konut (32) ifadeleri daha yüksek düzeyde konuma sahiptir. Katılımcıların verilerine ayrı ayrı bakıldığında da; belediyelerin en az önemli gördüğü diğer konular; 9, 17, 19, 14, 12, 31, 4, 21 ve 11 numaralı ifadelerde karşılık bulmaktadır. Bu ifadelerin içeriğine bakıldığında; en az önem verilen konular arasında ekonomi ve çevre ön plana çıkmaktadır. STK'lar açısından ise, en az önem verilen 
konular; 3, 20, 18, 10, 28 ve 26 numaralı ifadelerdir. Bu ifadelerin türü açısından bakıldığında; ekonomi ve sosyo-kültürel unsurlar ön plana çıkmaktadır".

Tablo 6. STK ve belediye yöneticileri tarafından katı atığa verilen önem

\begin{tabular}{|c|c|c|c|c|}
\hline & 36 & 24 & 36 & 24 \\
\hline \multicolumn{5}{|l|}{-4} \\
\hline-3 & STK1 & & & GBEL4 \\
\hline-2 & & STK1 & GBEL5 & \\
\hline-1 & & & GBEL1 & \\
\hline 0 & & STK2 & GBEL4 & \\
\hline \multirow[t]{2}{*}{1} & STK5 & STK6 & GBEL6 & GBEL3 \\
\hline & STK6 & STK5 & & \\
\hline \multirow[t]{2}{*}{2} & & STK3 & GBEL7 & GBEL6 \\
\hline & & & & GBEL1 \\
\hline \multirow[t]{3}{*}{3} & STK2 & STK4 & GBEL2 & GBEL2 \\
\hline & STK3 & & & GBEL5 \\
\hline & STK4 & & & GBEL7 \\
\hline 4 & & & GBEL3 & \\
\hline
\end{tabular}

Çalışmamızda Q-Metod'a konu olan sürdürülebilir kentsel kalkınma kriterleri arasında; "Çeşitli şekillerde ortaya çıkan atıkların, çevresel kirliliğe yol açmayacak şekilde çaba sarf etmek" (24) ve "Katı atıkların kaynakta ayrıştırılmasını ve geri dönüşümünü sağlamak" (36) ifadeleri ile atık konusuna yer verilmektedir. Așağıda hazırlanan Tablo 6 aracılığıyla atık yönetimi odaklı inceleme yapıldığında hem STK'ların hem de belediyelerin, kaynakta ayrıştırma ve geri dönüşüm dahil olmak üzere atık yönetimi konusuna 1 ile 4 aralığındaki dizilimde önem verdikleri anlaşılmaktadır.

\section{Sonuç}

Sürdürülebilirlik yaklaşımı, ekonomik, toplumsal ve çevresel konularda karşı karşıya gelinen sorunların giderilmesinde, uluslararası ölçekte üzerinde uzlaşı sağlanan bir çözüm arac1 olarak kabul görmektedir. Sürdürülebilirlik yaklaşımı, farlı alanlarda olduğu gibi kentler açısından da potansiyel çözüm önerileri sunmaktadır. Yaklaşımın kentlere yönelik sunduğu firsatların temel taşıyıcısı kent yönetimine dahil olan aktörlerdir. Aktörlerin algısı ve bilgisi, sürdürülebilirlik yaklaşımına kentsel düzlemde hayat kazandırmaktadır. $\mathrm{Bu}$ bağlamda araştırmada belediye ve STK'lardan oluşan aktörlerin sürdürülebilirlik algıları ölçülmeye çaba sarf edilmiştir. Ayrıca özelde de atık yönetimine ne derece önem verdikleri tespit edilmeye çalışılmıştır.

Elde edilen veriler üzerinden gerçekleştirilen faktör analizlerinde, STK grubunda beş, belediye grubunda ise üç faktör ortaya çıkmıştır. Faktör detaylarına bakıldığında her iki grupta da bir faktörde yoğunlaşmanın karşılık bulduğu görülmektedir. Diğer taraftan STK'lara kıyasla belediye grubunda daha fazla bir yoğunlaşmanın olduğu tespit edilmektedir. Belediyeler arasında sırasıyla; çevre, sosyo-kültürel, ekonomi ve yönetişim başlı̆̆ altındaki ifadeler üzerinde bir uzlaşının olduğu tespit edilmektedir. Belediyeler özelinde en güçlü uzlaşı, çocuklar için oyun alanları ve dezavantajlı birey ve toplulukların sosyal hayata katılımı konusundadır. Belediyeler arasında nüfus ve yerleşim özelliklerine göre; ulaşım hizmetleri, yeşil işletmelerin teşvik edilmesi, internet aracılığıyla kamusal erişim, atık yönetimi gibi bazı hususlarda uzlaşma olmadığı tespit edilmektedir.

\footnotetext{
${ }^{9} \mathrm{Bu}$ noktada belediye web sayfalarında veya yerele odaklanan web sayfalarında inceleme yapılan kentler ile ilgili sorunların tespit edilmeye çalışıldığı anketler hakkında bilgi vermek yerinde olacaktır. Bu bağlamda, incelendiği gün (19.12.2015) itibariyle 1724 kişinin katılım gösterdiği giresunblog.com'da gerçekleştirilen anket sonuçları incelendiğinde, Giresun'un en önemli üç sorununun sırasıyla; ișsizlik ve istihdam, aksu mahallesi çöp sorunu ve turizmin gelișememesi sonucuna ulaşılmıștır. Piraziz Belediyesi web sayfasında, hangisine daha fazla önem vermeliyiz? başlıklı ankete, incelenen gün (19.12.2015) itibariyle 217 kişi katılım göstermiş, sonuçlar ise; çevre düzenlemesi $\% 40$, turizm $\% 25$, ulaşım $\% 12$, kültürel faaliyetler $\% 11$ ve sportif faaliyetler $\% 7$ şeklinde belirlenmiştir. Yine benzer şekilde, sizce Bulancak ilçesinin sorunları nelerdir? başlığıyla Bulancak Belediyesi web sayfası üzerinden yürütülen anketin 19.12.2015 tarihli sonuçlarına göre de; yol/kaldırım/park \%44, aile için sosyal mekanlar \%16,8, altyapı eksiklikleri \%16,5, spor alanları\&tesisler 13,4 ve kültürel etkinlikler $\% 8,4$ şeklinde ortaya çıkmaktadır.
} 
STK'lar bağlamında faktör sonuçları incelendiğinde, daha dağınık bir görünüm tespit edilmektedir. Özellikle uzlaşıya varılmayan hususlarda bu dağınık durum daha fazla öne çıkmaktadır. Uzlaşılan konular ise daha çok çevre başlı̆̆ 1 altında ön plana çıkarken, uzlaşılmayan konular ise sosyo-kültürel ana başlığında ön plana çıkmaktadır. Belediye ve STK'lar birlikte ele alındığında ise; hırsızlık olaylarının giderilmesi ve azaltılması, farklı tarafların dahil edilmesi ve karmaşık sorunlarda farklı tarafların bir araya gelmesi konularında uzlaşının varlığı tespit edilmektedir. Diğer taraftan yine her iki grup birlikte ele alındığında; atık yönetimi ve tarım alanları ve su kaynaklarının korunması konusunda uzlaşının varlı̆̆ 1 tespit edilememektedir. Aktörler arasında uzlaşı sağlanan ortak noktaların varlığı, iş birliklerinin gelişmesinde önemli bir unsurdur. Yerleşim alanlarının özelliklerine bağlı farklılıklar ortaya çıkmakla birlikte, asıl önemli unsurun farkındalık ve bilgi eksikliğinden kaynaklandığı kanaati oluşmaktadır.

Elde edilen bulgulara katı atık yönetimi kapsamında odaklanıldığında, STK temsilcilerinin ve Belediye yöneticilerinin katı atıkların sürdürülebilir yönetilmesine yönelik algıları, tutumları yüksek olmakla birlikte, bir katılımcının belirttiği üzere, yeterince bilgi sahibi olmadıkları anlaşılmakta, ayrıca fiili olarak gerçekleşen çalışmaların sınırlı düzeyde kaldığ görülmektedir. Benzer şekilde 2007 yılında yapılan araştırmada da, belediye yöneticilerinin; entegre katı atık yönetimi, geri kazanım, geri dönüşüm, tarafların birlikteliği, sürdürülebilirlik vb. başlıklarda tutumları yüksek düzeyde yansımaktadır (Akdoğan ve Güleç, 2007, s. 59-60). Yine Türkiye'de Çevre Yönetimi için Kurumsal Kapasitenin Geliştirilmesi Projesi (ÇEKAP) kapsamında yapılan Çevre Yönetimi araştırması sonuçlarına göre de; ilçe, büyükş̧ehir ilçe, il merkezi ve büyükşehir ölçeğinde, atık yönetimi belediyelerin birinci öncelikleri olarak konumlandırılmaktadır (Doğru, 2016, s. 58). İfade edilenler bağlamında yine bir katılımcının da altını çizdiği üzere, kent düzleminden hukuki açıdan yetkili ve sorumlu bir birim olarak belediye yöneticileri ve çalışanları nezdinde, bilgi düzeyinin artırılması amacıyla çevre konusunda hizmet içi eğitimlere ihtiyaç duyulmaktadır. Atıklar konusunda yeterli bilgi sahibi olunmadığında, örneğin, kartonun 1slanmasıyla oluşan kaybın anlaşılmaması gibi, atıklar iyi yönetilemeyecektir.

İfade edilenler bağlamında sürdürülebilir bir kentsel kalkınmanın gerçekleşmesi için şu ilkelerin üzerinde önemle durmak gerekecektir: öncelikle bir sürdürülebilirlik vizyonunun belirlenmesi; uzun dönemde gerçekleşecek ekonomik ve sosyal güvencelerin sağlanması; biyolojik çeşitliliğin ve doğa ekosistemin farkında olunması, korunması ve restore edilmesi; ekolojik ayak izinin minimize edilmesi; kalkınma sürecinde ekosistemin dikkate alınması; kentlerin kendine özgü tarihi, doğal, kültürel özelliklerinin dikkate alınması ve geliştirilmesi; vatandaşları dahil edici bir yaklaşımın benimsenmesi; iş birliği ağlarının oluşturulması ve genişletilmesi; sürdürülebilir üretimin ve tüketimin teşvik edilmesi; hesap verebilirlik, açıklık ve iyi yönetişim hususunda sürekli iyileştirmelerde bulunulması (ilkelerin hayata geçmesine yönelik detaylı bilgi için bkz. Newman ve Jennings, 2008).

\section{Kaynakça}

Agranoff, R. ve Mcguire, M. (2003). Collaborative public management: New strategies for local governments. Washington, DC.: Goorgetown University Press.

Akbulut, F. ve Beren, F. (2012). Terörle mücadelede bütüncül yaklaşımın sosyal politika uygulamaları bağlamından algılanması: Suruç İlçesi örneği. Akademik İncelemeler Dergisi (Journal of Academic Inquiries), 7 (2), 257-283.

Akdoğan, A. ve Güleç, S. (2005). Belediyelerde katı atık yönetimi ve il belediyelerinde gerçekleştirilen ampirik bir araştırma. Çağdaş Yerel Yönetimler, 14 (4), 51-78.

Aykan, S. (2014). İstanbul'da kentsel sürdürülebilirlik. A. Bartu Candan ve C. Özbay (Ed.), Yeni Istanbul çalışmalar: Sinırlar, mücadeleler, açılımlar içinde (s. 241-261). İstanbul: Metis Yayınları. 
Barry, J. ve Proops, J. (1999). Seeking sustainability discourses with Q Methodology. Ecological Economics, (28), 337-345.

Bumin, K.(2010). Demokrasi arayışındaki kent. Konya: Çizgi Kitapevi.

Cohen, S. (2011). Sustainability management: lessons from and for New York City, Americ, and The Planet. New York: Columbia University Press.

Cullinan, C. (2014). Vahşi hukuk: bir yeryüzü adaleti manifestosu (M. Güneşdoğmuş, Çev.). İstanbul: Ayrıntı Yayınları.

Cuppen, E., Breukers, S., Hisschemöller, M. veBergsma, E. (2010). Q Methodology to select participants for a stakeholder dialogue on energy options from biomass in the Netherlands. Ecological Economics, (69), 579-591.

Çetinkaya, Ç. (2013). Eko-Kentler: Kent ve doğa ilişkisinde yeni bir sistem tasarımı. Türk Bilimsel Derlemeler Dergisi, 6 (1), 12-16.

Demir, F. ve Kul, M. (2011). Modern bir araştırma yöntemi Q Metodu. Ankara: Adalet Yayınevi.

Demir, F. (2013). Kamu politikası sürecinde müzakerenin rolü ve sürecin demokratikleştirilmesi. A. Kaptı (Ed.), Kamu politikası süreci: Teorik perspektifler, modeller ve analiz yöntemleri içinde (s. 205-236 ). Ankara: Seçkin Yayıncılık.

Dinler, Z. (2014). Bölgesel iktisat. Bursa: Ekin Kitapevi.

Doğru, B. (2016). Sürdürülebilir şehirler için katılımcılık, akılcılık, liderlik, ölçme ve yaptırım. EkoIQ, (62), 56-59.

Doody, D.G., Kearney, P., Barry, J., Moles, R. ve O'Regan, B. (2009). Evaluation of the QMethod as a method of public participation in the selection of sustainable development indicators. Ecological Indicators, (9), 1129-1137.

Edwards, A. D. (2005). The sustainability revolution portrait of a paradigm shift. Canada: New Society Publishers.

Eley, C. C. (2008). Absolutely positively wellington: A model for smart growht. L. C. Heberle ve S. M. Opp (Ed.), Local sustainable urban development in a globalized world içinde (s. 33-44). England: Ashgate Publishing Limited.

Engelman, R. (2013). Sürdürülebilirlik sakızının ötesi, dünyanın durumu 2013: Sürdürülebilirlik hâlâ mümkün mü? (C. Ulutaş Ekiz ve Ç. Ekiz, Çev.). İstanbul: Türkiye İş Bankası Kültür Yayınları.

Fiorino, D. J. (2010). Sustainability as a conceptual focus for public administration. Public Administration Review, 70 (1), 78-88.

Frantzi, S., Carter, N. T. ve Lovett, J. C. (2009). Exploring discourses on international environmental regime effectiveness with Q Methodology: A case study of the Mediterranean Action Plan. Journal of Environmental Management, (90), 177-186.

Furuseth, O. J., Lord, J. D. ve Barcus, H. (1999). Defining and measuring neighborhood sustainability in Charlotte, North Carolina. Applied Geographic Studies, 3 (1), 1-21.

Gültekin, M., Burak, D. ve Yaşar, E. (2018). Eğitim fakültesi akademisyenlerinin mesleki kimlikleri: $Q$ Metodolojik bir araştırma. 27. Uluslararası Eğitim Bilimleri Kongresi, 18-22 Nisan 2018, Antalya, Özet kitabı içinde (s. 3215-3218)

Harmon, K. M. (2008). Moving toward urban sustainability: A comparison of the development of sustainability indicators in Seattle and Minneapolis. L. C. Heberle ve S.n M. Opp (Ed.), 
Local sustainable urban development in a globalized world içinde (s. 93-110). England: Ashgate Publishing Limited.

Hiremath, R. B., Balachandra, P., Kumar, B., Bansode, S. S. ve Mural1, J. (2013). Indicatorbased urban sustainability a review. Energy for Sustainable Development, 17 (6), 555-563.

Jenks, M., Burton, E. ve Williams, K. (1996). Compact cities and sustainability: An introduction. M. Jenks, E. Burton ve K. Williams (Ed.), The Compact City: A Sustainable Urban Form? içinde (s. 2-6). Oxford: Oxford Brookes University.

Kara, N. (2006). Feminizm(ler)in toplumsal hareket olarak medyada yansıma(ma)sı. Küresel İletişim Dergisi, (1), 1-33.

Karakurt, E. (2008). Sürdürülebilir kentsel yaşam açısından sosyal sermayenin rolü. "İ̧̧, Güç" Endüstri İlişkileri ve Insan Kaynakları Dergisi, 10 (2), 76-100.

Keleş, R. ve Hamamc1, C. (2005). Çevre politikası. Ankara: İmge Kitapevi.

Keivani, R. (2010). A Review of the main challenges to urban sustainability. International Journal of Urban Sustainable Development, 1 (1-2), 5-16.

Kılınç, İ. (2011). Çöp Ekomisi ya da Atık “dedikleri”. Ankara: Epos Yayınları.

Kuban, B. (2014). Yerel seçimler için sürdürülebilir kentler şartı: Yeni bir şey söylemek mümkün mü?. EkoIQ, Mart, 28-36.

Leach, M., Scoones, I. ve Stirling, A. (2010). Dynamic sustainabilities: Technology, environment, social justice. London and Washington, DC.: Earthscan.

Lehmann, S. (2012). Optimizing urban material flows and waste streams urban development through principles of zero waste and sustainable consumption. S. U. Azeem ve S. B. Rav (Ed.), Sustainable Solid Waste management içinde (s. 102-132). Toronto ve New Jersey: Apple Academic Press.

Maczulak, A. (2010). Sustainability: Building eco-friendly communities (green technology), New York: Infobase Publishing.

Mori, K. ve Christodouleu, A. (2012). Review of sustainability indices and indicators: Towards a new city sustainability index (CSI). Environmental Impact Assessment Review, (32), 94106.

Newman, P. ve Kenworthy, J. (2000). Sustainable urban form: The big picture. K. Williams, E. Burton ve M. Jenks (Ed.), Achiving Sustainable Urban Form, London: E\&FN Spon.

Newman, P. ve Jennings, I. (2008). Cities as sustainable ecosystems: Principles and practices. Washington, DC: Island Press.

Özgül, C. G. (2015). Avrupa Birliği’nin sürdürülebilir kentsel gelişme politikaları. A. Çoban (Ed.), Yerel yönetim, kent ve ekoloji: Can Hamamcı'ya armağa içinde (s. 111-1329). Ankara: İmge Kitabevi.

Portney, K. E. (2003). Taking sustainable cities seriously economic development, the environment and quality of life in American cities. Massachusetts London: The MIT Press Cambridge.

Portney, K. ve Berry, J. M. (2010). Participation and the pursuit of sustainability in U.S. cities. Urban Affairs Review, XX (X), 1-21.

Promoting Sustainable Urban Development in Europe Achievements and Opportunities (2009). https://ec.europa.eu/regional_policy/en/information/publications/guides/2009/promotingsustainable-urban-development-in-europe-achievements-and-opportunities (Erişim tarihi: 25. 02. 2019). 
Raje, F. (2007). Using Q Methodology to develop more perceptive insights on transport and social inclusion. Transport Policy, (14), 467-477.

Rana, M. P. (2009). Sustainable city in the global North and South: Goal or principle?. Management of Environmental Quality: An International Journal, 20 (5), 506-521.

Rydin, Y. (2010). Governing for sustainable urban development. London: Earthscan.

Saha, D. ve Paterson, R. G. (2008). Local government efforts to promote the "Three Es" of sustainable development survey in medium to large cities in the United States. Journal of Planning Education and Research, (28), 21-37.

Scerri, A. ve James, P. (2010). Accounting for sustainability: Combining qualitative and quantitative research in developing 'indicators' of sustainability. International Journal of Social Research Methodology, 13 (1), 41-53.

Scoones, I. (2007). Sustainability. Development in Practice, 17 (4-5), 589-596.

Skelcher, C., Sullivan, H. ve Jeffares, S. (2013). Hybrid governance in european cities: Neighbourhood, migration and democracy. US.: Palgrave Macmillan.

Tağmat, T. S. (2009). Yerel yönetim modelleri ve katılımc1 süreçler: Avrupa'da güncel belgeler. Erişim adresi: http://www.mo.org.tr/mimarlikdergisi/index.cfm?sayfa=mimarlik\&DergiSayi=360\&RecID= 2014 (Erişim tarihi: 15.10.2012).

Tanguay, G. A., Rajaonson, J., Lefebvre, J.F. ve Lanoie, P. (2010). Measuring the sustainability of cities: An analysis of the use of local indicators. Ecological Indicators, (10), 407-418.

Tosun, E. K. (2010). Kentsel ekolojinin korunması bağlamında sürdürülebilir kentleşme yaklaşımı. B. Parlak (Ed.), Yerel yönetimler, yerel siyaset ve kentsel politikalar içinde (s. 375-392). Bursa: Dora Yayın Basım Ltd. Şti.

Wheeler, S. (1996). Sustainable urban development: A literature review and analysis. IURD Monograph Series, Institute of Urban and Regional Development. UC Berkeley, Erişim adresi: http://escholarship.org/uc/item/6mx0n01x (Erişim tarihi:11.11.2014).

Zafir, C. Z. (2014). Sürdürülebilir kalkınma yaklaşımı. A. F. Aysan ve D. Dumluoğlu (Ed.), Kalkınmada yeni yaklaşımlar içinde (s. 243-276). Ankara: İmge Kitabevi.

Zavadskas, E. K., Kaklauskas, A., Vainiūnas, P. ve Saparauskas, J. (2004). A model of sustainable urban development formation. International Journal of Strategic Property Management, 8 (4), 219-229.

Zeemering, E. S. (2009). What does sustainability mean to city officials?, Urban Affairs Review, 45 (2), 247-273.

ETİK ve BİLIMSEL İLKELER SORUMLULUK BEYANI

$\mathrm{Bu}$ çalışmanın tüm hazırlanma süreçlerinde etik kurallara ve bilimsel atıf gösterme ilkelerine riayet edildiğini yazar(lar) beyan eder. Aksi bir durumun tespiti halinde Afyon Kocatepe Üniversitesi Sosyal Bilimler Dergisi'nin hiçbir sorumluluğu olmayıp, tüm sorumluluk makale yazarlarına aittir. 